\title{
Principals Leadership Styles and Students' Academic Performance in Enugu Metropolis: A Comparative Survey of Public and Mission Secondary Schools
}

\author{
Nicholas Ngozi Igwe, Ph.D \\ Department of Business Management \\ Godfrey Okoye University, Ugwuomu Nike, Enugu \\ Ozofor Ndidiamaka M., Ph.D \\ Department Of Mathematics \&Computer Sciences \\ Godfrey Okoye University, Ugwuomu Nike, Enugu \\ Alinno Francis Chidi, Ph.D \\ Department Of Business Administration And Management, \\ Akanu Ibiam Federal Polytechni, Uwana Afikpo, Ebonyi State
}

\begin{abstract}
Education is a fundamental human right enshrined in all major United Nations and International Charters. As a result, there is need to provide it in most efficient manner. Education plays a major role in social emancipation, political, economic and cultural development of countries. However, the low performance of teachers and its negative impact accentuated by the dwindling fortunes of students' academic performance have become a great concern to major stakeholders in the education sector. The study compares the leadership styles of principals in public and mission secondary schools on students' academic performance in Enugu South Local Government Area of Enugu State, Nigeria. Ex-post facto descriptive research design was adopted. Data collection instruments were the use of structured questionnaire and interviews. The Yamane's (1964) statistical formula was used for sample size determination. A total of 285 copies of the questionnaire were administered to principals, teachers and supportive staff of the selected Secondary Schools using simple random sampling techniques. A combination of chi-square and Pearson product moment correlation statistical tools at 0.05 level of significance was utilized. Results of the investigation reveal that autocratic leadership style was positively correlated with students' academic performance. The study recommends that the application of autocratic leadership style by principals has the capacity of increasing the level of students' academic performance.
\end{abstract}

Key words: Principal, Leadership Style, Academic performance, Public, Mission.

\section{INTRODUCTION}

The society has various organizations among them educational institutions. Educational institutions especially secondary schools have become significant as a result of the importance placed on education (Budohi, 2014). An educational institution refers to a group of individuals in a given environment whose efforts are deliberately co-ordinated by principals for the purpose of imparting knowledge, skills and attitudes to students or pupils in order to achieve predetermined educational objectives or goals (Okumbe, 1998). These educational organizations include secondary schools which have aims and objectives to achieve and principals/leaders to co-ordinate its activities.Leadership is a broad concept that has been described and defined variously by philosophers, scholars, researchers and even laymen. It is as old as man and his interactions in the universe which involves both simple and complex ramifications. Leadership is the process of influencing the activities of a group of people by a 
leader in efforts towards goal achievement (Nworgu, 1991 and Nwadiani, 1998). It involves a force that initiates action in people and the leader. Leadership could be described as the ability to get things done with the assistance and co-operation of other people within the school system (Aghenta, 2001). Nowadays, the role of principal is to emphasize his or her activity as the transformational and instructional leader. This is because effectiveness is ultimately determined by the impact of the principal on students' learning outcome. Most of the research findings in the literature strongly correlate that the principal is the most important person in providing leadership for improved instruction and better curricular in order to enhance highacademic excellence in educational performance, (Adeyemi and Bolarinwa, 2013, Kythreotis, Pashiardis and Kyriakides, 2010 and Ibrahim, 2003). It is important to deal with effective leadership styles performed by the principals as these indeed play the most important role for effective schools and determining students' excellence in academic performance. Contributing and accentuating to the above discourse, outstanding leadership invariably emerged as a key characteristic of outstanding schools. There is no doubt that those seeking quality in education must ensure its presence in quantum proportion and that the development of potential leaders must be given high priority (Abrar, Baloch and Ghouri, 2010).

Thus it is arguable that management and leadership styles are very important for the running of the various organisations including secondary schools. In line with this argument, Ball (1987) had identified the following leadership and management styles which emerged in the course of his research in British secondary schools:the interpersonal managerial style, adversarial and the political style or authoritarian style. He described interpersonal head teachers/principals as being typically mobile and visible with a preference for consulting with individuals rather than holding meetings. They like to "sound out ideas" and gather opinions. Such head teachers will frequently reiterate to teachers the importance of bringing complaints and grievances to them first. Ball (1987) pointed out that this type of leadership style is particularly effective at satisfying teachers' individual needs and that grievances and staff turnover tend to remain low in such schools. On the other hand, he argued that principals/head teachers with managerial styles adopt a leadership style that parallels that of a manager in an industry. Nevertheless, Nsubuga (2008), argues that the use of management techniques involves the importation into the school system, types of relationships and processes of organizational control from the factory. The secondary school administrators in Nigeria are called principals (Duze, 2012 and Chidiobi, 2012) and are surrounded by school senior management team called the vice principals. The principals relate to the staff through this team and through a formal structure of staff meetings. Consequently, when the management team functions well through the principal's leadership, the school operations are well supervised and students perform well in their examinations. The principal is an important personality in the governance and management of the school for several reasons which include but are not limited to the following: liaising with Vice Principals and Head of Departments in upholding the culture of the school; maintaining school ethics and discipline;management of school funds; management of the general welfare of staff and students; soliciting support for the school from the host community and developing the quality and standards of education (Obama; Eunice and Orodho, 2015). It should be observed that some aspects of school management such as instructional, administrative, democratic and bureaucratic leadership styles are always good, coercive and authoritarian management styles are always frowned at and are therefore not conducive. It is against this background that this study was prompted and sought to compare the leadership styles of principals and students' academic performance in public and mission secondary schools in Enugu South Local Government Area of Enugu State especially given the ferocious agitations that preceded the formal hand over of schools to these missionary owners by the Enugu State Government in 2000. 


\section{STATEMENT OF THE PROBLEM}

The current global upsurge towards the acquisition of quality education has created anxiety in the hearts of stakeholders in the education sector on the types of leadership styles which school administrators/principals should adopt for effective and efficient implementation of national curriculum which would pave way for high educational output. This quest for the Golden Fleece had seen many wealthy and literate Nigerians 'catapulting' their wards and/or children out of the country to acquire the best quality education money can 'buy'. This sudden realization for quality education has received top priority in most Sub-Saharan African countries including Nigeria (Adeyemi and Bolarinwa, 2013; Orodho, 2014 and STAN, 1992). Demand for education quality is also increasing in Enugu South Local Council Government of Enugu State where the current administration in the state views the satisfactory performance of her basic education system not only instrumental but also strategically in relation to economic development and national competitiveness of her indigenes in the Nigerian project.Despite the fact that both public and missionary schools in Enugu South have qualified principals using differing leadership styles the academic performance in these schools have become a nightmare for stakeholders (Ahmadu, Yunus, Norwaris and Musa, 2012) and Obemeata, (1992).

There is no gain saying the fact that academic performance of students in Senior Secondary Schools Certificate (SSCE) examinations is determined by many factors, leadership style plays a very significant role in the quality of education delivery. Studies by scholars and researchers have established the consensus that principals' leadership styles have significant impact on student's performance and achievement in external and national examinations such as West African Senior School Certificate Examination (WASSCE) and National Examination Council (NECO) respectively. However, some of these studies produce varying results and only very few are in agreement witheach other's findings. Research has shown that in secondary schools where management principles like delegation, teachers' participation in decision making process, clear communication channels, human relations and modern instructional techniques are practiced, students' academic performance tend to improve greatly. It has been documented that in some secondary schools in the Enugu State some principals abdicate their duty and divorce themselves from statutory responsibility and authority entrusted to them leading to poor students' academic performance. This practice is very much common in rural schools with low supervision by Ministry of education and Post Primary School Management Board (PPMB).

Again no research study has delved into comparing the leadership styles of public and missionary schools principals and its impact on students' academic achievements. The current study was conceived to investigate the difference if any of leadership styles of principals in public and missionary secondary schools on students' academic performance since primary and secondary schools were 'de-regulated' and many handed over to their former owners the missionary by the then government of Enugu State between 1999 - 2007.

\section{PURPOSE AND OBJECTIVES OF THE STUDY}

The purpose of the study is a comparative study of secondary school principals in public and missionary schools in Enugu South LGA. The objectives this study seeks to investigate are as follows:

1. To examine the level of academic performance of students in public and missionary secondary schools where the most commonly used leadership style is practiced.

2. To determine which leadership style is the best for Public and/or Missionary Secondary School in Enugu South Local Government Council. 


\section{KEY RESEARCH QUESTIONS}

From the foregoing, the following key research questions were deciphered:

1. To what extent is the level of students, academic performance improved by the most commonly used leadership style in public and missionary schools?

2. What should be the best leadership style for a public and mission secondary schools in Enugu South L.G.A.?

\section{RESEARCH HYPOTHESES}

A hypothesis is a tentative statement of the relationship between two or more variables (Spiegel, 1992; Ozofor, 2012). In line with the main purpose and objectives defined in the foregoing the following hypotheses are formulated for the study:

$\mathbf{H}_{\mathbf{0}}$ : There is no correlation between principals' leadership styles and the level of students' academic performance in public and missionary secondary schools in Enugu South L.G.A.

$\mathbf{H}_{\mathbf{1}}$ : There is a correlation between principals' leadership styles and the level of students' academic performance in public and missionary secondary schools in Enugu South L.G.A.

$\mathbf{H}_{\mathbf{o}}$ : There is no best leadership style of principals for public and mission secondary schools in Enugu South L.G.A.

$\mathbf{H}_{1}$ : There is the best leadership style of principals for public and mission secondary schools in Enugu South L.G.A.

\section{Conceptual Framework}

\section{REVIEW OF RELATED LITERATURES}

Much effective school research over the past two decades has concentrated on examining the relationship between the leadership behavior of school principals and the enhancement of organizational performance (Shum \& Cheng, 1997). Of particular interest has been studies that highlighted the mediating role principals serve between teachers and learners (Silins\& Murray-Harvey, 1999). Interestingly, results from these studies have suggested that principals have the ability to indirectly affect student achievement by improving the tone or learning environment of a school (Johnson, Livingston, Schwartz \& Slate, 2000).However, while the concepts of school leadership and school learning environment seem to be intuitively linked, there has been few studies that have related these concepts together (Griffith, 1999). Furthermore, recent paradigm shifts in conceptualizing leadership have also encouraged educational researchers to consider these relationships from the perspective of new leadership models. Prominent among them is the transformational and transactional leadership model (Burns, 1978) which suggests that follower performance can be lifted to beyond what is normally considered to be acceptable (Bass, 1985). Again, transformational leaders are able to manipulate and alter their environmental constraints in order to achieve performance goals (Kirby, King and Paradise, 1992).

Adeyema and Bolarinwa (2013),brought into focus a dimension of leadership style that is associated with the autocratic/democratic continuum. This is the task orientation-versus relationship-oriented style of leadership with the task orientation being similar to the autocratic method and the relationship oriented style being similar to the democratic method. According to the authors, current research has established that the difference between the effectiveness and ineffectiveness of the four leadership styles is the appropriateness of the leader's behavior to the particular situation in which it is used. With respect to the foregoing, Duze (2012) states that one of the basic factors that would elevate or debilitate each of the four 
leadership styles is the basic task maturity of the individual or group being led with maturity being defined in terms of the capacity to set high but realistic goals.

Kemp and Nathan (1989) identified three styles of leadership namely authoritarian, democratic or delegative, and or laissez-faire. According to Adeyemi (1998) the authoritarian or autocratic leadership style is used when leaders tell their employees what they want done and how they want it accomplished, without getting the advice of followers. This style results in the group members reacting aggressively and uninterestingly in the work environment. They further suggest that authoritarian style should normally only be used on rare occasions. This often results in unending industrial disputes in an organization hence affecting the achievement of the overall goals and objectives. The participative or democratic leadership style involves the leader including one or more employees in the decision making process in determining what to do and how to do it. However, the leader maintains the final decision making authority. Using this style is not a sign of weakness; rather, it is a sign of strength that your employees will respect (Obama, Eunice and Orodho, 2015).

Nsubuga (2008) maintains that an effective principal pays more attention to planning work, special tasks and permits teachers to participate in decision-making processes in an effort to achieve school goals. Using this style is of mutual benefit. It allows them to become part or the team and allows you to make better decisions. According to Ogunasanwo, (2000) the participatory leadership style provides a climate of sense of unity in pursuit of set goals.

Delegative or free reign is where the leader allows the employees to make the decisions. This is used when employees are able to analyze the situation and determine what needs' to be done and how to do it. The laissez-faire style of leadership, according to Flippo and Munsinger, (1982) is where a leader succumbs to Theory Y. The theory argues that people are innately motivated, naturally like to do work and therefore there should be no rules since everybody has an inborn sense of responsibility. However, this style of leadership may result in indiscipline due to non-enforcement of rules and regulations in a school leading to poor performance in both national and external examinations.

Pervasive and sustained student learning is more likely to occur in schools with strong instructional leadership. Morphet, Johns and Reller (1974) stress that administrative efficiency will be valid only to the extent to which it will contribute to the attainment of goals of the organization, the goals of actors in the organization and the extent that it will meet the requirements of the environment for that survival of the organization. Bell (1992) notes that effective leadership will provide schools with a vision, explicit philosophies laid on consultation and team work and lead to success in attainment of good results in national examinations. Abrar, Baloch and Ghour (2010) further assert that incompetent principals are a big problem to the overall administration and management of education in any country.

\section{Empirical Studies Reviewed: Leadership and Students' Academic Performance}

The term 'academic performance' has been described as the scholarstic standing of a student at a given moment. It refers to how an individual is able to demonstrate his or her intellectual abilities. This scholarstic standing could be explained as the grades obtained in a course or groups of courses taken (Daniels and Schouten, 1970), Owoyemi, 2000). Animola, (1990) commented on the scholarstic standing of students and argued that performance is a measure of output and that the main outputs in education are expressed in terms of learning, that is, changes in knowledge, skills and attitudes of individuals as a result of their experiences within the school's system. Thus, in determining academic performance, Daniels and Schouten (1970) emphasized the use of grades in examinations and reported that grades could serve as 
predictive measures as well as criterion measures. Findings made by AI-Shorayye (1995) and Adeyemi (1998) gave credence to this point.

Academic performance therefore is largely identified by a range of statistical indicators. Science Teachers Association of Nigeria (STAN, 1992) supported this argument and reported that performance is the level of attainment of a person in an examination, that is, how an individual is able to demonstrate his or her abilities in an examination. Performance has been regarded as a measure of educational output (Adeyemi, 2006). This fact buttressesObemeata's (1992) argument that the performance of students in public examinations in many Nigerian schools has been poor as a result of shortage of teachers, inadequate funding of schools and the broad secondary school curriculum. Supporting these findings, Animola (1990) expressed that this poor performance of students has been a great concern to curriculum planners and stakeholders in the education sector.

Omotoso (1992) attributes the causes of dwindling performance of students in Nigerian schools to the poor financial position of government which has made the funding of schools inadequate. This situation has placed a greater burden on the Parents Teachers Associations which is saddled with the funding of most capital projects in schools. The introduction of the Structural Adjustment Programme by the Federal Government of Nigeria in 1986 led to the rising cost of textbooks and stationery in Nigeria. Hence, the running grants to schools were often delayed and grossly inadequate in view of the rising cost of living (Ige, 2001). Ibukun (1990) supported this view and reiterated that poor training of teachers, lack of textbooks and inadequate facilities often lead to poor educational results. As a result, he asserted that the educational system in Ondo State, Nigeria is being seriously challenged, as it appears to be true in opinion of many people that the standard of the educational enterprise is falling in the State.

Principals play a significant role in determining the academic performance in secondary schools due to their varied tasks and roles together with their constant supervision of their teachers determined to a great extent the level of teacher input and students' academic achievement (Budohi, 2014). Many of them have failed in school leadership because of many management problems relating to institutional planning, human relations, discipline, instructional supervision and community relations experienced which ultimately impact on students' academic performance. Studies carried out by many scholars indicate that students' academic achievement is mainly dependent on environmental factors and personal factors of the students (Okumbe, 1998). Students' personal factors include intelligence, discipline and personal goals. Environmental factors include the principals' leadership style, quality and quantity of teachers and learning materials (Olaniyan, 1999) finance (Okumbe, 1998) and home environment (Griffith, 1999).

Commenting on the inadequacy of physical facilitates in schools, Animola (1990) remarked that there were over-crowded classrooms especially in urban schools and the absence of laboratory facilities in many rural schools thereby inhibiting effective teaching and learning processes. This situation tends to have adverse effect on students' academic performance in schools.Towards this end, Adeyemi, (1998) conducted a study on schools and teacher variables associated with students' academic performance in Ondo State secondary schools and found that students' performance in the major subject of the school curriculum was at a low level. Similar finding were made by other researchers (Aghenta, 2000; Ige, 2001).It needs to be mentioned, however, that the pattern of scoring in the senior secondary certificate examinations was such that: A1 to $\mathrm{C} 6$ are credit grades. As such, students are required to 
obtain credit grades in 5 subjects including English Language and Mathematics in order to qualify for admissions into higher institutions in Nigeria (WAEC, 2010).

In essence failure to master their leadership roles and lack of proper induction/training on school leadership are probably the most frequently cited reasons why most principals fail to improve on student's academic performance and objectives. Effective leadership style is essentially a tool which principals should use to raise teachers' job efficiency and consequently improve the dwindling academic performance of students in both national and external examinations.

\section{METHODOLOGY}

The researchers adopted ex-post facto descriptive research design. Ex-post facto research is a systematic empirical study in which a researcher does not have direct control over the independent variables because they have already occurred (Onyeizugbe, 2013).The design was appropriate in this study because the variables: Leadership styles of principals and students' academic performance had already occurred. Thus the researchers merely analyzed the nature of relationships. The objective of the study was to carefully compare the leadership styles exhibited by principals in public and missionary secondary schools in Enugu South Local Government Area of Enugu State Nigeria. The instruments for data collection were questionnaire and oral personal interviews. The population of the study was 992 staff of both public and missionary owned secondary schools. This data was generated from the PostPrimary School Management Board (PPSMB) Agbani Zone in charge of secondary schools' supervision as at $25^{\text {th }}$ January, 2015.The Yamane's (1964) statistical formula was employed for sample size determination (Appendix I). The questionnaire and structured oral personal interview were developed by the researchers.The questionnaire instrument was validated by senior colleagues of the researchersexperienced and knowledgeable in the construction of research instruments. Consequently, some items were added while a few others were rewritten in line with the research objectives.

The computed sample size was allocated proportionally to the selected public and missionary owned secondary schools using Kumar (1976) proportionate allocation formula (Appendix II).The questions were optioned using a five (5) point Likert type of responses namely: Strongly Agree, Agree, Neutral, Disagree and strongly disagree.

The study also included oral personal interviews with principals who agreed to be interviewed. The principals were asked to indicate their availability and willingness in the questionnaire. As expected, the principals would be most likely to provide information on leadership styles and students' academic performance.

A total of 285 copies of the questionnaire were administered to principals, teachers and supportive staff of the selected secondary schools. Out of this number, ten(10) were not returned, five (5) was unusable due to improper filling by respondents. As a result, two hundred and seventy (270) were utilized indicating a return rate of 98 percent. The quantitative data were analyzed using chi-square and Pearson product moment correlation statistical tools at 0.05 level of significance. These techniques were adopted because the samples of the variables were randomly selected from the population (Igwe, Nwokedi and Udeh, 2014). 
Table 1.0 Questionnaire Distribution

\begin{tabular}{|c|l|c|c|}
\hline S/N & \multicolumn{1}{|c|}{ QUESTIONNAIRE } & $\begin{array}{c}\text { NO OF } \\
\text { RESPONDENTS }\end{array}$ & PERCENTAGE \\
\hline 1 & Returned & 275 & 96.5 \\
\hline 2 & Not returned & 10 & 3.5 \\
\hline 3 & Not used & 5 & 2.0 \\
\hline 4 & Used & 270 & 98.0 \\
\hline & Total distributed & $\mathbf{2 8 5}$ & $\mathbf{1 0 0 . 0}$ \\
\hline
\end{tabular}

Source: From questionnaire administration, 2015.

\section{RESULTS AND DISCUSSION}

In this study a comparative analysis of leadership styles of principals was compared to the level of students' academic performance in public and missionary schools in Enugu South Local Government Area of Enugu State. In this section therefore the findings in relation to the objectives of the study are presented and discussed.

\section{Computation of hypothesis 1 (one)}

\section{Principals' leadership styles and level of students' academic performance}

\section{Objective 1 (one)}

To examine the level of academic performance of students in public and missionary secondary schools where the most commonly used leadership style is practiced.

\section{Research question 1 (one)}

To what extent is the level of students, academic performance improved by the most commonly used leadership style in public and missionary schools?

\section{Relevant Questions:}

Question numbers 23 and 24

23. Autocratic leadership style increases academic performance of students.

24. Paternalistic leadership styles increases students' academic performance

Table 2.0

Contingency table on the correlation between leadership styles and increase in level of academic performance of students.

\begin{tabular}{|l|l|l|c|c|c|}
\hline $\begin{array}{l}\text { N(paired } \\
\text { values of X } \\
\text { and Y) }\end{array}$ & $\begin{array}{l}\text { Autocratic } \\
\text { leadership } \\
\text { styles } \\
\text { increasing } \\
\text { the level of } \\
\text { academic } \\
\text { performance } \\
\text { = X }\end{array}$ & $\begin{array}{l}\text { Participative } \\
\text { leadership } \\
\text { style } \\
\text { increases the } \\
\text { level of } \\
\text { academic } \\
\text { performance } \\
=\mathrm{Y}\end{array}$ & $\mathbf{X}^{2}$ & $\mathbf{Y}^{2}$ & $\mathbf{X Y}$ \\
\hline $\begin{array}{l}\text { Strongly } \\
\text { Agree }\end{array}$ & 120 & 125 & 14400 & 15625 & 15000 \\
\hline Agree & 80 & 85 & 6400 & 7225 & 6800 \\
\hline No opinion & 60 & 40 & 3600 & 1600 & 2400 \\
\hline Disagree & 10 & 20 & 100 & 400 & 200 \\
\hline $\begin{array}{l}\text { Strongly } \\
\text { Disagree }\end{array}$ & 00 & 00 & 00 & 00 & 00 \\
\hline N = 5 & $\sum \mathrm{x}=270$ & $\sum \mathrm{Y}=270$ & $\sum \mathrm{x}^{2}=24500$ & $\sum \mathrm{Y}^{2}=24850$ & $\sum \mathrm{XY}=24400$ \\
\hline
\end{tabular}




$\begin{array}{lll}\text { Test statistic } & = & \text { Pearson's Product moment correlation coefficient } \\ \text { Degree of freedom (df) } & = & 3 \\ \text { Number of pairs } & = & 5 \\ \text { Level of significance } & = & 0.05 \\ \text { Critical value } & = & 2.35 \\ \gamma & = & 0.97 \\ \text { Calculated value } & = & 6.86\end{array}$

\section{Source: Statistical Analysis (Appendix III)}

The computation of $\gamma$ using the raw value of 0.97 indicated a strong positive correlation between leadership styles of autocratic and participative styles of principals and increase in the level of academic performance of students in the secondary school certificate examinations. From the above, it becomes necessary to make inference about the population as to whether the correlated coefficient obtained is an indication of a real relationship between positive principal leadership styles and academic performance of students in senior secondary school certificate examination (SSCE).

The test statistic used to realize this objective is the t-test.

\section{Solution:}

$\mathrm{N}=$ Number of pairs $=5$

$\mathrm{Y}=0.97$

Level of significance $\quad=\quad 0.05$

Degree of freedom $\quad=\quad n-2$

$=5-2$

$=3$

Decision rule: Reject Ho if $\mathrm{t}$ - computed is greater than $\mathrm{t}$ - critical, otherwise do not reject (accept).

$\mathrm{t}-$ critical from the table $=2.35$

Computation of $\mathrm{t}$ from sample: For detailed computation and transformation of Pearson's Product moment Correlation to $\mathrm{t}$ - test (see Appendix III).

Decision: $\mathrm{t}$ - computed $6.86>\mathrm{t}-$ critical $(2.35)$.

Therefore, we reject Ho and accept the alternate hypothesis which states that there is a significant relationship between principals' autocratic leadership styles and level of students' academic performance in senior. Secondary School Certificate Examination at the public and mission secondary schools in Enugu South L.G.A.

\section{Finding}

The finding of the objective one shows that the null hypothesis was rejected after the computational analysis.

The finding of this computational analysis reveals a strong positive correlation between the leadership styles of autocraticprincipals and students' academic performance at senior secondary school certificate examinations $n$ the sampled schools (Table 4.3.4). The findings in respect of the hypothesis agreed with the findings of Adeyemi, (1998) and Adeyemi and Bolarinwa (2013). The strong positive correlations found in this study attests to the fact that the more autocratic a principal in the schools curriculum implementations the better the academic performance of the students. This suggests that principals who show no nonsense 
inclinations in students' academic performance achieve better results in external examinations especially in WAEC and NECO. This finding extols the need to compel and police students in order for them to study and perform better. Thus the administrative strategy of theory $\mathrm{X}$ becomes paramount especially in public schools with low moral values.

\section{Computation of hypothesis two (2)}

The search for best leadership styles of Principals in Public and Mission Secondary Schools in Enugu South L.G.A.

\section{Objective 2 (two)}

To determine which leadership style is the best for a Public and/or Missionary Secondary School in Enugu South Local Government Council.

\section{Research Question 2 (two)}

What should be the best leadership style for a public and mission secondary schools in Enugu South L.G.A.

\section{Relevant Questions}

Questions 28 and 33 of the questionnaire

28. Autocratic Leadership style is best for Public Secondary Schools

33. Paternalistic leadership is best for a missionary secondary schools

Table 3.0

Contingency table on evaluation of the best leadership style for public and mission secondary schools

\begin{tabular}{|c|c|c|c|c|c|c|}
\hline Options & \multicolumn{6}{|c|}{ RESPONSES } \\
\hline & SA & $\mathbf{A}$ & $\mathbf{N}$ & DA & SD & $\begin{array}{l}\text { Row } \\
\text { Total }\end{array}$ \\
\hline Autocratic leadership style is best for public secondary schools & 20 & 10 & 40 & 80 & 120 & 270 \\
\hline $\begin{array}{l}\text { Paternalistic leadership style is best for mission secondary } \\
\text { schools }\end{array}$ & 10 & 10 & 30 & 90 & 130 & 270 \\
\hline Column Total & 30 & 20 & 70 & 170 & 170 & 540 \\
\hline
\end{tabular}

Table 4.0

The Computed observed and expected frequencies of sample result Options

\begin{tabular}{|l|c|c|c|c|c|c|}
\hline & SA & A & N & DA & SD & $\begin{array}{c}\text { Row } \\
\text { Total }\end{array}$ \\
\hline $\begin{array}{l}\text { Autocratic leadership style is best for } \\
\text { public secondary schools }\end{array}$ & $20(15)$ & $10(10)$ & $40(35)$ & $80(85)$ & $120(125)$ & 270 \\
\hline $\begin{array}{l}\text { Paternalistic leadership style is best for } \\
\text { mission secondary schools }\end{array}$ & $10(15)$ & $10(10)$ & $30(35)$ & $90(85)$ & $130(125)$ & 270 \\
\hline Column Total & $\mathbf{3 0}$ & $\mathbf{2 0}$ & $\mathbf{7 0}$ & $\mathbf{1 7 0}$ & $\mathbf{1 7 0}$ & $\mathbf{5 4 0}$ \\
\hline
\end{tabular}

Test statistic

$\begin{array}{ll}= & \mathrm{x}^{2} \\ = & 4 \\ = & 0.05 \\ = & 9.49 \\ & =\end{array}$

Source: Statistical Analysis (Appendix VI) 


\section{Decision}

Since the computed value 5.73 is less than the critical value (9.49), we accept the null hypothesis and reject the alternative hypothesis. We conclude therefore that there is no best leadership style suitable for public or missionary secondary schools applied by principals.

\section{Finding}

The finding of the study shows that the null hypothesis was accepted after the computational analysis. Table 4.0 reveals that the respondents did not agree that there is one best leadership style for schools administration. This finding agrees with the assertions of Chidiobi (2012) that there is no one best leadership style that gets the job done. She rather advocates a mix of the leadership styles applied based on situation. This is because leadership styles and motivation tend to depend for effectiveness on the cultural patterns of the environments. Collaborating the above assertions, Akpala (1993) opines that managerial action to motivate subordinates is principally a question of art or managerial judgment applied contingently.

\section{CONCLUSION}

This investigation asserts that leadership styles of principals are a critical variable in the administration and management of both public and mission secondary schools in Enugu South Local Government Area of Enugu State. This was evident in the findings which isolated that autocratic leaderships style of principals has the capacity of enhancing students' academic performance in national and external examinations. The study is also of the view that there is no single best leadership style for high performance principals rather a mix is advocated and should be applied based on contingency.

\section{RECOMMENDATIONS}

1. Autocratic leadership is suggested to principals desirous of improved academic standards especially in increasing the level of students' academic performance in external examination.

2. Since there is no single best leadership style for any situation it is recomended that training and development programme should be given to principals and vice principals to update them with current global leadership style that achieve results. This training can be designed during the long vacation just before the resumption of new academic session.

3. Regular school inspection by the Ministry of Education in collaboration with the Post Primary School Management Board (PPSMB) should ensure that the leadership style utilized by principal is the one that improve teacher job performance. This will definitely enhance administrative effectiveness thereby improving the academic tone of the schools.

\section{AREAS FOR FUTURE RESEARCH}

This study has provided insights into leadership styles as utilized by principals of public and mission secondary schools in Enugu South Local Government Area. Consequently, it opens new vistas of opportunities for scholars in the education field and Management Sciences across Nigeria and other countries to conduct further research in the following areas.

1. Interested scholars are encouraged to investigate the leadership style that could best improve the job performance of supportive non-teaching staff in the school system.

2. The impact of leadership styles of Head teachers of primary schools on job performance of teachers could be investigated.

3. A similar comparative study could be done for high profile non-mission private schools and government schools. 


\section{References}

Abrar, N., Baloch, A.G. and Ghour, A.M. (2010). Attitude of Secondary School's Principals and Teachers toward inclusive Education: Evidence from Karachi, Pakistan. European Journal of Social Sciences, 15(4) 573-582.

Adeyemi, T.0. (1998). School and teacher variables associated with the performance of students in the Senior Secondary School Certificate Examination in Ondo State Nigeria. Unpublished Ph.D Thesis, University of Hull, England, United Kingdom; 2-25.

Adeyemi, T.0. (2006). Fundamentals of Educational Management, Lagos: Atlantic Associated Publishers, pp: 21 60.

Adeyemi, T.O. and Bolarinwa, R. (2013). Principals' Leadership Styles and Student Academic Performance in Secondary Schools in Ekiti State, Nigeria in International Journal of Academic Research in Progressive Education and Development 2(1), 187-198.

Aghenta, J.A. (2001). Educational Planning.A turning point in education and development in Nigeria.Inaugural Lecture Series 58 University of Benin, Benin-City, Nigeria.

Ahmadu, A.R., Yunus, N.K.Y. Norwanis N.M. and Musa, K. (2012).Organisation Commitment of Public School Senior Head Teachers.International Journal of Economics, Business and Management Studies 1(1), 9-14.

Akpala A. (1993). Management: An introduction and the Nigerian Perspective, Enugu: Dept. of Management, Faculty of Business Administration, UNEC (Publishers).

Al-Shorayye, S.R. (1995). The effect of admissions policy, socio-economic factors, and demographic and personal considerations on students' performance at Kuwait University. Unpublished Ph.D Thesis, University of Hull Uk, $142-145$.

Animola, R. B. (1990). 'Laying a solid foundation for science Education Development in OndoState.History of Educational Development in Ondo State'. A Multi-Disciplinary Review, Olu-Aderonumu W.O. (ed) Ikere-Ekiti: Seminar, Research and Publications Committee, Ondo State College of Education March, 98.

Ball, S.J. 1987. Politics and policy making in education: Exploration in policy sociology. London: Routledge and Kegan Paul.

Bell L.G. (1992).Managing teams in Secondary Schools. New York: Routledge.

Budohi, L. A., (2014). The effect of principals' leadership styles on the academic achievement of student in public secondary schools in Lurambi division, Kakamega county Kenya. Unpublished Master of Education of Kenyatta University.

Burns, J.M. (1978). Leadership.Ewyork: Haper and Row, Publishers. Campbell, R.F., Bridges, E.M. \&Nystrand, O. R. (1993).Introduction to Educational Administration (6 ${ }^{\text {th }}$ Ed). Boston: Allyn and Bacon.

Chidiobi, R.U. (2012). Administration of Secondary Education (Principalship). Enugu: God's Will Prints (Publishers), pp. 50-57.

Daniels, M. and Schouten, J. (1970). Education in Europe: the screening of students, problem of assessment and prediction of academic performance. Council for cultural co-operation of the council of Europe. London: George Harrap Co. Ltd., 65.

Duze C.O. (2012). 'Leadership Styles of Principles and Job Performance of staff in Secondary Schools in Delta State of Nigeria'.An International Journal of Arts and Humanities. Ethiopia: AFRREV IJAH 1(2) 224-245.

Filippo, E. E. and Munsinger, G. M. (1982).Management, Boston: Allyn and Bacon Inc. (Publishers).

Griffith, J. (1999). The school leadership/school climate relation: Identification of school configurations associated with change in principals. Educational Administration Quarterly, 35 (2), 157-191. 
Ibrahim, M.K.M. (2003) Per Kaitan Gaya KepimoinanPengetuaDenganKepuasanKerja Dan Pengajaran Guru. (The Relationship of Principal Leadership styles, Job Satisfaction and Teaching instruction of teachers). KoleksiAbstrakDisertasiKedoktoranPendidikan du Malaysia, Retrieved from http://www.moe.gov.com.

Ibukon, O. (1990). The Future of Education in Ondo State. History of Educational Development in Ondo State: A Multi-Disciplinary Review, Olu-Aderonwu W.O. (ed) Ikere-Ekiti, Seminar, Research and Publications Committee, Ondo State College of Education, March.

Ige, J.A. (2001). Teacher data in Secondary Schools in Ekiti State. Speech delivered by the Permanent Secretary at the Senior Staff Seminar, Ministry of Education, Ado-Ekiti, pp: 1-9.

Igwe, N.N., Nwokedi, R.C. and Udeh, S.N. (2014). An empirical investigation into the impact of change management on selected manufacturing firms in South East Nigeria. International Journal of Business Administration, Vol.5 No.1. www.sciedu.ca/ijba.

Kemp, R. and Nathan, M. (1989). Middle Management in Schools: A Survival Guide. London: Basil Wall Ltd.

Kirby, P.C., King, M. I., and Paradise, L.V. (1992). Extraordinary Leaders in Education: Understanding Transformational Leadership. Journal of Educational Research, 85(5), 303-311.

Kumar, R. S. (1976). A manual of sampling techniques, London: Heinemann Limited.

Kythceotis, A., Pashiardis, P. and Kyriakides, L. (2010).The influence of school leadership styles and culture on students' achievements in Cyprus Primary Schools.Journal of Educational Administration, Netherlands: Kluwer Academic Publishers.

Morphet, E.L, Johns, R.L. \&Reller.T.L.(1974).Educational Organisation and Administration Concepts, Practices and issues. New Jersey: Prentice Hall.

Nsubuga, Y.K., (2008). Analysis of Leadership Styles and School Performance of Secondary Schools in Uganda.Ph.D Thesis Nelson Mandela Metropolitan University.

Nwadiani, (1998).Educational Management for sub-Saharan African.Nigeria Society for Educational Planning. Nworgu, B.G. (1991). Educational Research: Basic Issues and Methodology. Wisdom Publisher Ltd. Ibadan.

Obama, M.O., Eunice L.A. and Orodho J.A.(2015). Effect of principals' leadership styles on students' academic performance in public secondary schools in homa-bay County, Kenya.IOSR Journal of Humanities and Social Science. 20 (3) pp 51-60.

Obemeata, J.O. (1992) "Raising the Standard of performance public Examinations in Nigeria" Ibadan; Paper presented at the WAEC Symposium on Raising the standard of Performance in Public Examinations, University of Ibadan, April.

Ogunsanwo, O.A. (2000). "Modern Principles and Techniques of Management". Ibadan: External Studies Programme, Department of Educational Management, University of Ibadan 2, 4-90.

Okumbe, J.A., (1998). Educational Management Theory and Practice. Nairobi: University Press.

Olaniyan, A.O. (1999). Principal Preparation, Selection and Leadership Roles, Teachers and Teaching in Nigeria. Benin Festa Press Ltd., pp: 73-88.

Omotoso, D (1992)How to make 3-3 Secondary School Component of the New System of Education work in Ondo State, Akure: Paper presented to all Nigeria Conference of Principals of Secondary Schools (ANCOPSS) April.

Onyeizugbe, (2013).Practical Guide to Research Methodology in Management. Onitsha: Good Success Press.

Orodho, A.J. (2014). Attainment of education for all (EFA) by 2015: From rhetoric chimera to practice in Kenya. International Journal of Current Research.Vol. 6. Issue 10, pp4666-44674. January 2014, www.journalcra.com.

Spiegel, M.R. (1992).Theory and Problems of Statistics. New York: McGraw Hill Publishers.

STAN (1992) "Raising the Performance of Students in Public Examinations in Science, Technology and Mathematics" Paper Presented at the WAEC Symposium held at the University of Ibadan Nigeria, 24th April, pp: 16,14 .

WAEC (2010).Statement of Result. Lagos West African Examination Council, 1-2.

Yamane, T. (1964).Statistics: An Introductory Analysis. London: Harper and Row. 


\section{APPENDIX I}

In calculating the sample size, the researcher applied the statistical formula for selecting from a finite population as determined by Yamane (1964).

The formular is stated as follows:

$$
\mathrm{n}=\frac{\mathrm{N}}{1+\mathrm{N}(\mathrm{e})^{2}}
$$

Where:

$\mathrm{n}=$ Sample size

$\mathrm{N}=$ the entire population

$\mathrm{I}=$ theoretical constant

$\mathrm{e}=$ proportion of sampling error in a given situation, in this case (0.05)

Assigning values to these symbols, the sample size was calculated thus:

$$
\begin{aligned}
& n=\frac{992}{1+992(0.05)^{2}} \\
& =\frac{992}{1+992(0.0025)} \\
& =\frac{992}{1+2.48} \\
& =\frac{992}{3.48} \\
& =285.06
\end{aligned}
$$




\section{APPENDIX II}

After calculating, the sample size we allocated this value proportionately to the secondary schools namely public owned and missionary owned respectively. This was facilitated through the use of Kumar (1976) proportionate allocation formula. It is given by:

$$
\mathrm{nh}=\frac{\mathrm{n}(\mathrm{Nh})}{\mathrm{N}}
$$

Where:

$\mathrm{Nh}=$ group population from each stratum

$\mathrm{n}=$ overall sample size

$\mathrm{N}=$ overall population

$\mathrm{nh}=$ sample size from each stratum, in this case each secondary school.

Table 3.1: Distribution of questionnaire among the secondary schools in Enugu South L.G.A.

\begin{tabular}{|c|l|c|c|}
\hline S/N & \multicolumn{1}{|c|}{$\begin{array}{c}\text { NUMBER OF } \\
\text { SECONDARYSCHOOLS }\end{array}$} & $\begin{array}{c}\text { NUMBER OF } \\
\text { STAFF }\end{array}$ & $\begin{array}{c}\text { NUMBER OF } \\
\text { QUESTIONNAIRE }\end{array}$ \\
\hline 1 & Public Secondary Schools (5) & 602 & 173 \\
\hline 2 & $\begin{array}{l}\text { Mission owned Secondary schools } \\
(5)\end{array}$ & 392 & 112 \\
\hline & Total (10) & $\mathbf{9 9 2}$ & $\mathbf{2 8 5}$ \\
\hline
\end{tabular}

Source: Field Survey, 2015.

Table 3.2: Distribution of respondents based on organizational level.

\begin{tabular}{|c|l|c|c|}
\hline S/N & \multicolumn{1}{|c|}{ ORGANISATIONAL LEVEL } & $\begin{array}{c}\text { NUMBER OF } \\
\text { RESPONDENT }\end{array}$ & PERCENTAGE \\
\hline 1 & Principals & 10 & 3.50 \\
\hline 2 & Teaching staff & 225 & 78.95 \\
\hline 3 & Non-Teaching (Supportive) Staff & 50 & 17.55 \\
\hline & Total (10) & $\mathbf{2 8 5}$ & $\mathbf{1 0 0 . 0 0}$ \\
\hline
\end{tabular}

Source: Field Survey, 2015. 


\section{APPENDIX III}

\section{COMPUTATION OF HYPOTHESES THREE FROM SAMPLE RESULT}

Applying the Pearson Product Moment Correlation Coefficient's formula as symbolically defined as:

$Y=\frac{N \quad X Y-(X)(Y)}{\sqrt{\left[N \quad X^{2}(X)^{2}\left[N \quad Y^{2}(Y)^{2}\right.\right.}}$

Substituting the values as obtained:-

$$
\begin{aligned}
& Y=\frac{5 \times 24400-(270)(270)}{\sqrt{\left[5 ( 2 4 5 0 ) ( 2 7 0 ) ^ { 2 } \left[5(24850)^{2}(270)^{2}\right.\right.}} \\
& =\frac{122000-72900}{\sqrt{(12250072900)(12425072900)}} \\
& =\frac{49100}{\sqrt{(49600)(51350)}} \\
& =\frac{49100}{\sqrt{2546960000}} \\
& =\frac{49100}{50467.42} \\
& =0.9729
\end{aligned}
$$

\subsection{7}

Computation of $\mathrm{t}$ from sample

$t=\sqrt[r]{\frac{n-2}{n-r^{2}}}$

Where

$\mathrm{t}=\mathrm{t}-$ statistic

$r=$ Correlation coefficient

$\mathrm{n}=$ number of paired values

$\mathrm{n}-2$ = degree of freedom

By substituting the values

$$
\begin{aligned}
& t=\sqrt[0.97]{\frac{5-2}{1-(0.97)^{2}}} \\
& =\sqrt[0.97]{\frac{3}{1-(0.9409)}}
\end{aligned}
$$




$$
\begin{aligned}
& =\sqrt[0.97]{\frac{3}{1-(0.06}} \\
& =\sqrt[0.97]{50} \\
& =0.97 \times 7.07 \\
& =6.8589 \\
& =6.86
\end{aligned}
$$

\section{Computation of coefficient of determination}

To support the g correlation coefficient, there is need to compute further the coefficient of determination, $\mathrm{g}^{2}$ so that we can assess the residual error.

Thus

$\mathrm{g}=0.97$

$\mathrm{g}=0.97^{2}$

$=0.9409$ 


\section{APPENDIX IV}

\section{COMPUTATION OF HYPOTHESES FOUR FROM SAMPLE RESULT}

Test statistic: The chosen test statistic is Chi-square $\left(\mathrm{x}^{2}\right)$ is applied at 5 percent level of significance.

Let $\mathrm{x}=0.05$

Degree of freedom $\mathrm{df}=(\mathrm{r}-1)(\mathrm{c}-1)$

$$
\begin{aligned}
& =(5-1)(2-1) \\
& =(4)(1) \\
& =4
\end{aligned}
$$

The Critical Value $=9.49$

To compute the expected, we apply

$$
\begin{aligned}
& \frac{(\text { row total })(\text { column total })}{\text { overall total }} \\
& \text { ej(i) }=\frac{270 \times 30}{540}=15 \\
& \text { ej(ii) }=\frac{270 \times 20}{540}=10 \\
& \text { ej(iii) }=\frac{270 \times 70}{540}=35 \\
& \text { ej(iv) }=\frac{270 \times 170}{540}=85 \\
& \text { ej(v) }=\frac{270 \times 250}{540}=125 \\
& x^{2}=\frac{(O j-E j)^{2}}{\text { ej }} \\
& =0+0 \\
& x^{2}(i)=\frac{(20-15)^{2}}{15}+\frac{(10-15)^{2}}{15} \\
& =1.67+1.67 \\
& =3.33
\end{aligned}
$$


$\mathrm{x}^{2}(\mathrm{iii})=\frac{(40-35)^{2}}{35}+\frac{(30-35)^{2}}{35}$

$=0.71+0.71$

$=1.42$

$\mathrm{x}^{2}(\mathrm{iv})=\frac{(80-85)^{2}}{85}+\frac{(90-85)^{2}}{85}$

$=0.29+0.29$

$=0.58$

$\mathrm{x}^{2}(\mathrm{v})=\frac{(120-125)^{2}}{125}+\frac{(130-125)^{2}}{125}$

$=0.2+0.2$

$=0.40$

Total $=3.33+0.00+1.42+0.584+0.40=5.73$

$\therefore 5.73>9.49$ 


\section{APPENDIX V}

\section{CONSENT TO PARTICIPATE IN RESEARCH: A COMPARATIVE ANALYSIS OF LEADERSHIP STYLES OF PRINCIPALS IN PUBLIC AND MISSIONARY SCHOOLS IN ENUGU SOUTH LOCAL GOVERNMENT AREA OF ENUGU STATE}

\section{What is the purpose of this research?}

We are asking you to participate in a research study because we are trying to learn more about your understanding of leadership styles. You are invited to participate in this study because you are a Nigeria. This study is being conducted by Dr. Nick Igwe at Godfrey Okoye University Enugu.

\section{How much time will this take?}

This study will take about fifteen minutes of your time.

\section{What will I be asked to do if I agree to participate in this study?}

If you agree to be in this study, you will be asked to complete a questionnaire with information about leadership styles.

What are the risks involved in participating in this study?

Being in this study involves minimal risks of spending some of your time completing the questionnaire.

What are the benefits of this study?

Your participation in this study may contribute to policy change in the administration of secondary schools, in Enugu State Nigeria.

\section{Can I decide not to participate? If so, are there other options?}

Yes, you can choose not to participate. Even if you agree to be in the study now, you can change your mind later and leave the study. There will be no negative consequences if you decide not to participate or change your mind later.

\section{How will the confidentiality of the research records be protected?}

The records of this study will be kept confidential. In any report we may publish, we will not include any information that will identify you. Research records will be stored securely and only the researchers will have access to the records that identify you by name. Some people may review our records in order to make sure we are doing what we are supposed to. For example, the Godfrey Okoye University Institutional Research Board may review your information. If they look at our records they will keep your information confidential.

\section{Whom can I contact for more information?}

If you have questions about this study, please contact Dr. Nick Igwe 08038726688. If you have questions about your rights as a research participant, you may contact, Godfrey Okoye University's Coordinator of Research.

\section{Statement of Consent}

I have read the above information. I have all my questions answered. (Tick as appropriate). [ ] I consent to be in this study. [ ] I do not consent to be in this study. [ ] 
Signature:

Date:

Printed name:

\section{APPENDIX VI}

\section{QUESTIONNAIRE FOR RESEARCH STUDY ON: A COMPARATIVE ANALYSIS OF LEADERSHIP STYLES OF PRINCIPALS IN PUBLIC AND MISSIONARY SCHOOLS IN ENUGU SOUTH LOCAL GOVERNMENT OF ENUGU STATE.}

Dear Respondent,

\section{INTRODUCTION \\ SECTION A}

The enclosed questionnaire is purely a research tool designed for a Professional Diploma in Education (PDE) project to be submitted to the Institute of Ecumenical Education Thinkers Corner Enugu. You have been selected at random and that your response will be treated in utmost confidence. It is purely for academic purposes and as such your co-operation is highly solicited.

Thanks.

\section{Instructions}

To be completed by principals, teachers and supporting staff of secondary schools in Enugu South Local Government Area of Enugu State.

ii. Please carefully read each question before responding.

iii. Tick as appropriate in the spaces provided.

\section{SECTION B \\ INFORMATION ABOUT RESPONDENT AND HIS/HER SCHOOL}

1. Sex: Male [ ] $\quad$ Female [ ]

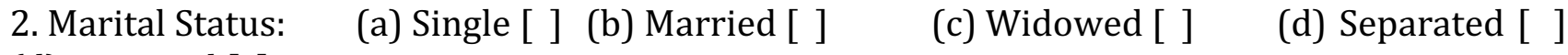

(d) Divorced [ ]

$\begin{array}{llll}3 . & \text { Age of Respondents: } & \text { (a) Less that } 20 \text { years [ ] } & \text { (b) } 20-30 \text { years [ ] }\end{array}$

(c) $31-40$ years [ ] (d) $41-50$ years [ ] (e) $51-60$ years

4. Religion: (a) Christianity [ ] (b) Muslim [ ]

(c) Other religions - please specify

5. What is your highest academic qualifications:
(a) M.Sc./M.Sc.Ed/M.Ed/M.A or above
(b) B.Ed./B.Sc.Ed/ B.Sc/HND
(c) N.C.E. (d) O.N.D. (e) WASC/G.C.E.

6. Name of your school
7. Your school is
(a) Less than 5 years [ ]
(b) $6-10$ years [ ]
(c) $11-15$ years [ ] (d)
16 - 20 years [ ]
(e) 21 years and above 

8. Number of years in service with the school
(a) $1-5$ years [ ]
(b) $6-10$ years
(c) $11-15$ years [ ]
(d) $16-20$ years
(e) 21 years and above

9. Department unit: (a) Teaching (b) Supportive staff (c) Principal

\section{SECTION C}

\section{LEADERSHIP STYLES OF PRINCIPALS IN SECONDARY SCHOOLS}

Key: (5) Strongly Agree (4) Agree (3) No - opinion (4) Disagree

(5) Strongly Disagree

To what extent do you agree that the following listed leadership styles are applied by principals of secondary schools: Autocratic, Paternalistic, Participative and Laisser-Faire.

LIKERT SCALE

\begin{tabular}{|c|c|c|c|c|c|c|}
\hline 10 & & 5 & 4 & 3 & 2 & 1 \\
\hline a. & Autocratic & & & & & \\
\hline $\mathrm{b}$. & Paternalistic & & & & & \\
\hline C. & Participative & & & & & \\
\hline $\mathrm{d}$. & Laisser-Faire & & & & & \\
\hline 11 & $\begin{array}{l}\text { Autocratic Leadership styles enhance } \\
\text { schools Administration }\end{array}$ & & & & & \\
\hline 12 & $\begin{array}{l}\text { Parternalistic Leadership styles enhances } \\
\text { school Administration }\end{array}$ & & & & & \\
\hline 13 & $\begin{array}{l}\text { Participative Leadership styles enhances } \\
\text { school Administration }\end{array}$ & & & & & \\
\hline \multirow[t]{2}{*}{14} & $\begin{array}{l}\text { Laisser-Faire Leadership styles enhances } \\
\text { school Administration }\end{array}$ & & & & & \\
\hline & $\begin{array}{l}\text { Leadership Styles And Teachers Job } \\
\text { Performance }\end{array}$ & & & & & \\
\hline 15 & $\begin{array}{l}\text { - Autocratic Leadership styles improves } \\
\text { teachers' job performance }\end{array}$ & & & & & \\
\hline 16 & $\begin{array}{l}\text { - Paternalistic Leadership styles improves } \\
\text { teachers' job performance }\end{array}$ & & & & & \\
\hline 17 & $\begin{array}{l}\text { - Participative Leadership styles improves } \\
\text { teachers' job performance }\end{array}$ & & & & & \\
\hline \multirow[t]{2}{*}{18} & $\begin{array}{l}\text { - Laisser-Faire Leadership styles improves } \\
\text { teachers' job performance }\end{array}$ & & & & & \\
\hline & $\begin{array}{l}\text { A mix of the leadership styles get the job } \\
\text { easily done. }\end{array}$ & & & & & \\
\hline 19 & $\begin{array}{l}\text { A mix of autocratic and paternalistic } \\
\text { leadership is good. }\end{array}$ & & & & & \\
\hline 20 & $\begin{array}{l}\text { A mix of Participative and partnership } \\
\text { leadership style. }\end{array}$ & & & & & \\
\hline 21 & $\begin{array}{l}\text { - A mix of participative and Laissez-Faire } \\
\text { leadership style and autocratic. }\end{array}$ & & & & & \\
\hline \multirow[t]{2}{*}{22} & - A mix of Laissez-Faire leadership style. & & & & & \\
\hline & Leadership style and level of students' & & & & & \\
\hline
\end{tabular}




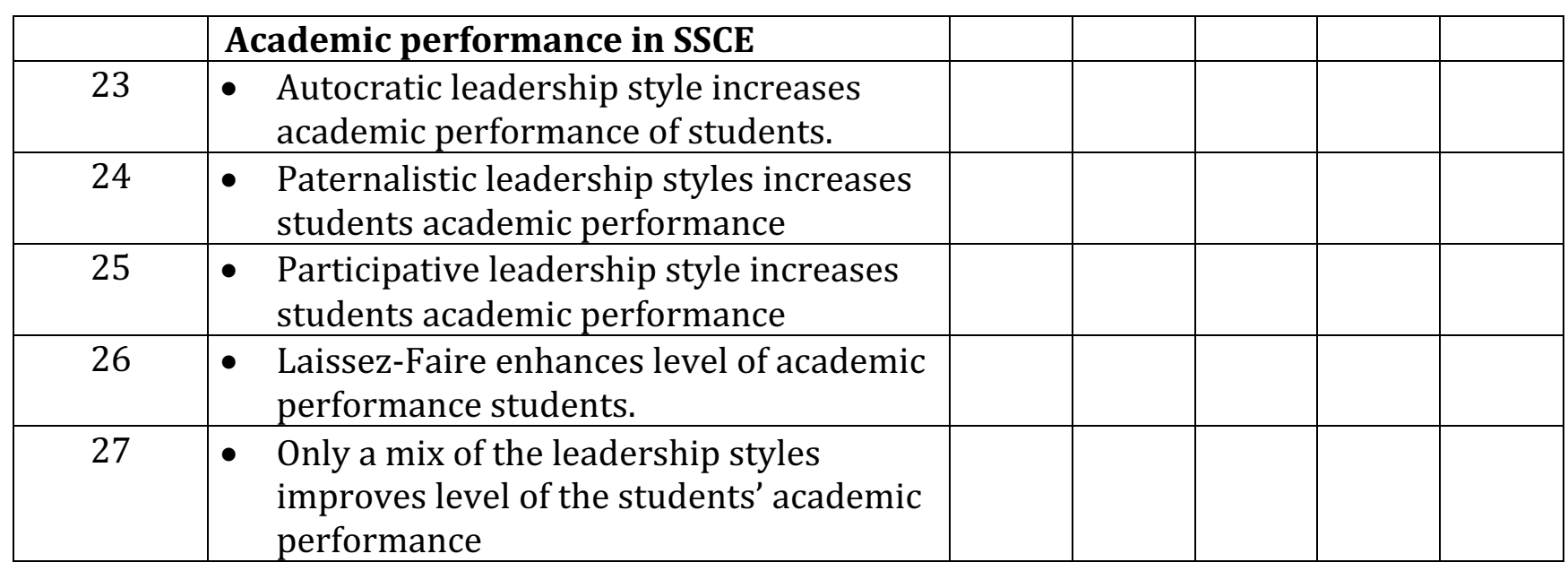

Evaluation of best leadership style for a public and missionary secondary schools

LIKERT SCALE

\begin{tabular}{|c|c|c|c|c|c|c|}
\hline & & 5 & 4 & 3 & 2 & 1 \\
\hline 28 & $\begin{array}{l}\text { Autocratic Leadership style is best for } \\
\text { Public Secondary Schools }\end{array}$ & & & & & \\
\hline 29 & $\begin{array}{l}\text { Paternalistic Leadership style is best for } \\
\text { Public Secondary Schools }\end{array}$ & & & & & \\
\hline 30 & $\begin{array}{l}\text { Participative Leadership style is best for } \\
\text { Public Secondary Schools }\end{array}$ & & & & & \\
\hline \multirow[t]{2}{*}{31} & $\begin{array}{l}\text { Laissez-Faire is best for Public Secondary } \\
\text { Schools }\end{array}$ & & & & & \\
\hline & A mixture of leadership is best & & & & & \\
\hline 32 & $\begin{array}{l}\text { - Autocratic leadership is best for a } \\
\text { missionary }\end{array}$ & & & & & \\
\hline 33 & $\begin{array}{l}\text { - Paternalistic leadership is best for } \\
\text { missionary schools }\end{array}$ & & & & & \\
\hline 34 & - Laisser-Faire is best for mission schools. & & & & & \\
\hline 35 & $\begin{array}{l}\text { Participative Leadership is best for } \\
\text { mission schools }\end{array}$ & & & & & \\
\hline 36 & - A mix is best for mission schools. & & & & & \\
\hline 37 & $\begin{array}{l}\text { - Not one leadership style is best for both } \\
\text { public and mission schools }\end{array}$ & & & & & \\
\hline 38 & $\begin{array}{l}\text { Would you mind to be interviewed for } \\
\text { further clarifications. }\end{array}$ & & & & & \\
\hline
\end{tabular}

Thanks for your attention and response.

Dr. Nicholas NgoziIgwe, MTRCN 


\section{APPENDIX VII}

\section{LIST OF PUBLIC SECONDARY SCHOOLS IN ENUGU SOUTH LOCAL GOVERNMENT OF ENUGU STATE}

1. Girls High School Uwani Enugu

2. Model High School Amechi

3. CSS AmoduAwkunanaw

4. CSS Ugwuaji

5. CSS Akwuke

6. CMSS Amechi-Uno

7. Maryland Boys Secondary School

8. Army Day Secondary School

9. Idaw River Girls Secondary School

10. CSS NdiaguAmechi

11. CSS ObeaguAwkunanaw

\section{MISSION OWNED SECONDARY SCHOOLS ADMINISTERED BY MISSIONARY PRINCIPALS}

1. C.I.C. Enugu

2. H.R.C. Enugu

3. Union Secondary School Awkunanaw

4. Girls Grammar School Awkunanaw

5. His Grace High School Awkunanaw

6. Notre Dame Secondary School

7. Methodist College Agbani Road

8. Emmanuel Anglican Secondary School Achara Layout Enugu

9. St. Raphael Secondary School Amechi 